\title{
THE EFFECTIVENESS OF ANTI MONEY LAUNDERING LAWS TOWARDS TANZANIAN ECONOMY
}

\author{
EVA LUDGER KOMBA \\ Mzumbe University \\ https://doi.org/10.37602/IJSSMR.2020.3408
}

\begin{abstract}
This paper discusses "The Effectiveness of Anti Money Laundering Laws Towards Economy of Tanzania". It introduces the conceptual aspect of money laundering in Tanzanian context, showing the history of money laundering and the need of regulation at domestic level as a response to the crime. Then, it focuses on Anti money laundering laws and financial institutions as the necessary means of preventing and controlling the crime. It explains various legislations on money laundering at domestic level and international cooperation due to its transnational nature of the crime. Evidently, in the findings the weakness of the law and enforcing agencies and this will be achieved only by intensifying the existing legislations and enforcing agencies as well. Furthermore, it analyses money laundering and its impacts to Tanzanian economy. It discusses the negative impacts of money laundering such as damaged financial institutions, inflation and distortion of competition market in the country. Then it goes on to discuss money laundering in the context of corruption and Tax evasion. Additionally, it discusses money laundering and macroeconomic stability as well as capital and trade flows in Tanzania. Then it deals with confiscation of laundered asset and asset recovery from money laundering criminals in Tanzania and challenges of controlling the crime which in one way or another hampered the development of the country. It concludes that money laundering is a very serious crime and has negative impact to the Tanzanian economy since huge amount of money end in the hands of few criminals for their personal benefits which could be used for economic development of the country. This paper calls upon government to create a strong legal and institutions framework so as to build strong economy in the country.
\end{abstract}

Keywords: Money Laundering, Anti Money laundering laws, Economy.

\subsection{GENERAL INTRODUCTION}

With trade liberalisation and globalisation, extra territorial economic activities have significantly increased. People can easily invest abroad and make their reserves in banks both domestic and abroad. With free movement of money facilitated by international transaction through commercial banks, many unfaithful businesspersons and political leaders have used this opportunity as loop hole of sanctifying illegal money (funds) in the country. ${ }^{1}$ This practice has some economic detriments in Tanzania.

${ }^{1}$ Doug Hopton, Money Laundering, (A Concise Guide For All Business), Routledge ,New York ,2016,Second Edition Pg. 2. Furthermore, in Tanzania large of our economy is cash based and an increase of mobile banking 


\section{International Journal of Social Sciences and Management Review}

Money laundering has great effects to the economic development of Tanzania. ${ }^{2}$ Although there is no clear statistics data on the money lost due to these activities under Financial Intelligence Unit $(\mathrm{FIU})^{3}$, the organisation which deals with money laundering in Tanzania, but there are number of cases which evidence the extent of money laundering problem in Tanzania. Some of the cases are James Burchard Rugemalira V.R ${ }^{4}$,Basil Pesambili Mramba and others V .R ${ }^{5}$,Marcus Mussa Masira and 7 others $V R,{ }^{6}$ with alleged amount of Tsh 671,212,379.92; Marcus Mussa Masira and 4 others $^{7}$ with alleged amount of Tsh 3,392,812,190.4,; Justice Lumima Katiti and 5 others ${ }^{8}$ with alleged amount of Tsh 3,802,017,775.57,; Hamud Ally Salum ${ }^{9}$ with alleged amount Tsh 562,861,500, and Mawazo Saliboka and 17 others ${ }^{10}$ with alleged amount Tsh 4,093,534,157.Following those few mentioned cases it is clear that a huge amount of money roughly Tsh 12,522,438,009.91 which could otherwise be used in the country budget has disappeared without any justification. From these data we can see the seriousness of the offence to Tanzanian Economy.

Furthermore, even the Bank of Tanzania which is used to control financial institutions including banks and non banks are involved in money laundering. For instance in the External Payment Arrears (EPA) cases the government of Tanzania lost US\$ 131 million $^{11}$ as well as their personnel have the same status as happened in the case of Amatus Joachimu Liyumba $V \cdot R^{12}$ who was the Director of Administration and personnel of the Bank of Tanzania (BoT) due to fraud which caused the loss of USD 153,077,715.71 which is equivalent to Tsh 222, 197,299.95.

This problem will end only by adopting proper control mechanisms on money laundering. Legal framework of the country and international instruments be vital players in reducing the risks that are attached to the offences of money laundering. One of the major reasons of enacting the Anti Money Laundering $\mathrm{Act}^{13}$ is the truth that money laundering is a serious worldwide problem as the Bill to enact Anti Money Laundering Act reads

Money laundering has become a major problem in the modern world. Countries in the world have decided to work together against an increasingly sophisticated combination of techniques, use of experts and professionals to disguise the true ownership and control of illegal proceeds. In that respect, the United Republic has decided to join efforts

such as MPESA, TIGOPESA, AIRTEL MONEY which operate without adhering to formal banking create vulnerabilities of financial sector.

2 Andre Standing and Hannie Van Vauuren, The role of Auditors: research into organised Crime and Money

Laundering, Paper No.73 Institute For Security Studies,2003,5

${ }^{3}$ Section 4 of Anti Money Laundering Act of 2006, RE 2019

${ }^{4}$ Criminal Appeal No 391 of 2017

${ }^{5}$ MSC CR .NO 54 of 2008

${ }^{6}$ Criminal Appeal No 428 of 2016.

${ }^{7}$ Ibid.,

${ }^{8}$ Ibid

9 Ibid.,

${ }^{10}$ CC 83/09 Nzega Resident Magistrate Court

${ }^{11} \mathrm{http}$ ///allafrica.com/stories/201108010647.html Accessed on 20th July 2020

12 Criminal Appeal No.56 of 2010 ,The High Court of Tanzania (Dar Es Salaam District Registry)

13 Anti Money Laundering Act of 2006 RE 2019 ,Cap 423 


\section{International Journal of Social Sciences and Management Review}

of the international community by enacting a law against such activities.

The Bill makes proposals for a comprehensive and consistent legal framework of measures for combating money laundering in Tanzania. ${ }^{14}$

Even though Tanzania enacted $\mathrm{Act}^{15}$ of Anti-Money Laundering, still there are number of acts which in one way or another amount to money laundering. The above cited cases are an example of some acts which amounts to money laundering. This raises some questions as to what is the reason behind continuation of money laundering activities despite having laws to combat this practice. Is it the weakness of the law or the enforcing agencies? Therefore, this paper seeks to find the actual reason for continuation of money laundering in the country and suggest possible ways of eliminating this problem which acts as an obstacle to the efforts of building a strong economy of the country.

\section{I.1 The Concept of Money Laundering}

Money Laundering is a process through which illicit funds are disguised as legitimate monies by concealing their true origin/source and ownership so that the funds can be used for the criminal or even non criminal, activities. ${ }^{16}$ In Tanzania, Money laundering is one of the ways which people use as a means of legalising illegally obtained money. ${ }^{17}$ Money laundering is a crime in Tanzania. This crime involves any kind of dealing with, engaging in, converting, transferring, transporting or transmitting, concealing, disguising or impeding the establishment of the true nature, source, location, disposition, movement or ownership, acquiring, possessing, using or administering, a property which is a proceed of a predicate offence. ${ }^{18}$

From the wording of the $\mathrm{Act}^{19}$ money laundering means engaging of a person or persons, direct or indirectly in conversion, transfer, concealment, disguising, use or acquisition of money or property known to be of illicit origin and in which such engagement intends to avoid the legal consequences of such action. The crime of Money laundering is mostly detected in financial institutions since are the ones authorized to keep huge amount of monies. ${ }^{20}$ The definition of the Act is so complicated in such a way even the employees or personnel in various institutions fail to understand, that is why it could be impossible for them to detect the offence and sometime engage to the offence unknowingly. ${ }^{21}$ Furthermore, the concept of Anti money laundering is used by banks and other financial institutions to describe the variety of measures for the purpose of combating illegal activity and to prevent

${ }^{14}$ The Bill of Anti Money Laundering Act of 2006: Objects and Reasons for enacting the Anti Money Laundering Act contained in the Bill to enact that Act.

${ }^{15}$ Anti Money Laundering Act of 2006 RE 2019,Cap 423

${ }^{16}$ Access Bank Tanzania, Banking Services Policy and Procedures, Anti money laundering and Know your customer, 2010, 13/126: Angela Veng Mei Leong, The Disruption of International Organised Crime: An Analysis of Legal and non-legal Strategies, [England: Ashgate Publishing Limited 2002], 30: The definition of money laundering differ from one country to another specifically developed and developing countries.

${ }^{17}$ Anti Money Laundering Act of 2006, RE 2019

${ }^{18}$ Ibid., Section 12

${ }^{19}$ Ibid., Section 3

${ }^{20}$ Elizabeth V Mulig and L Murphy smith, Understanding and preventing money laundering,( Internal Auditing and charities,2004),23.

${ }^{21}$ Supra ,note 10:Amatus Joachim Liyumba case 


\section{International Journal of Social Sciences and Management Review}

criminals from using individual banks and the financial system in general as the conduit for their proceeds of crime. ${ }^{22}$ In general the Anti money laundering has the effect of reducing the optimal level of money laundering in a country.

\subsection{The Stages of Money Laundering}

Money laundering can occur in many circumstances though money laundering operation can often be analysed in three essential stages, namely, placement, layering and integration. ${ }^{23}$ Placement is the initial stage whereby the criminal fund is set into the financial system which can be directly or indirectly and normally this stage takes place in a country where the funds originate. This process can be done by breaking up large amount of cash into less conspicuous smaller sums that are then deposited direct into a bank account, and sometimes can be through purchasing a series of monetary instruments. ${ }^{24}$

The breaking of cash into small amount and depositing that in various bank accounts is called structuring offence. In many developed countries this offence has been included in their laws as the offence of money laundering, but the structuring offence is yet to be officially recognized in Tanzania as a money laundering offence. ${ }^{25}$

Secondly, layering involves the separation of criminal proceeds from their source by using complex layers of financial transactions designed to hide the audit. Under this stage the launderer engages in a series of movement of the funds to distance them from their source. The funds might be channelled through the purchase and sales of investments or could be wired through series of accounts at various banks around the world. This stage is mostly used by criminals who are well developed technologically, for example, channelling funds through the internet. Thirdly, integration involves placing the laundered proceeds back into the legitimate economy in such a way that appears to be normal business funds. ${ }^{26}$ The processes of money laundering are the same all over the world. However, it is important to understand these three stages of money laundering crime in order to avoid confusing the offence of money laundering with simple theft which is not the case. The researcher has the view of identifies this offence of money laundering even after passing two stages unlike all of three state due to the seriousness of the offence.

\subsection{The Justification of Anti Money Laundering Laws}

As we evidenced through our discussion that a lot of money had been lost in Tanzania simply because of money laundering activities, this justifies the need of money laundering laws to remedy the situation. Money laundering is not a minor crime because it provides a medium and encouragement for possible growth of organised crimes in the community such as illegal

\footnotetext{
${ }^{23}$ Dough Hopton, Money Laundering: a Concise Guide for all Business,(Hampshire: Glower Publishing Limited,2006), 60

${ }^{24}$ Ibid., 67

${ }^{25}$ Peter Reuter and Edwin M.Truman, Chasing dirty money: the fight against money laundering ,( Washington D.C: Institute for International Economic, 2004),30

${ }^{26}$ Ismail A. Odeh,Anti-Money Laundering and Combating Terrorist Financing For Financing For Financial Institutions,(Pennsylvania: Dorrance Publishing Co,inc, 2010],3. See also http://www1.worldbank.org/finance/assets/image/PB9906-en.pdf.
} 


\section{International Journal of Social Sciences and Management Review}

printing of bank notes which can in turn undermine the legal order and socio-economic foundations of a country. ${ }^{27}$

Money laundering creates many negative externalities in the economy such as, financial pollution due to the fact that the laundering process requires more or less conscious involvement of financial intermediaries, it boost illegal financial revenue and financial assets that criminals can invest or reinvest in their activities. Furthermore, it creates economic power in the hand of criminal organisations which leads to their strong influence on a country's social and political life with a subsequent exacerbation of social pollution standard. ${ }^{28}$ The other reason of having anti money laundering laws is the characteristic of the offence, which is not limited to one country including, developed countries and developing countries like Tanzania. ${ }^{29}$ The justification of anti money laundering laws is based on nature of the offence and its dangerous impact on the economy specifically third world countries like Tanzania. ${ }^{30}$

\subsection{The Brief History of Money Laundering in Tanzania}

Money laundering is not a problem which originated in Tanzania; it was originated from other countries. It emerged in 1970s when the community engaged in activities which amounted to money laundering. From that period the word money laundering started to exist and some members of the general public became aware to the term. After that period many countries in recognition of the seriousness of the problem have tried to broaden the word money laundering to include capital flight, tax evasion, insider trading, bribery, corruption, misappropriation of public funds, arm trafficking, terrorism, prostitution and all activities which are associated with predicate offence. ${ }^{31}$

However, during that time money laundering activities had never been crimes since there were no legislations to deal with them until in the early 1980s when the United State senate investigated the matter at the banks and came up with the legislation called Anti Money Laundering Act 1986 which was the first legislation to deal with money laundering offence in the world. ${ }^{32}$ With the same spirit the international perspectives came up with various laws to deal with money laundering so as to help member countries to enact the domestic laws to deal with the matter. The international initiatives started to exist in 1988, through enactment of

\footnotetext{
27 Money laundering is a wider context associated with the economy's crime such as fraud, corruption, tax evasion, misappropriation of the public funds and terrorism.

${ }^{28}$ Donato Masciandaro, Global Financial crime: terrorism, money laundering and offshore centre (England: Ashgate Publishing Limited, 2004), 189.

${ }^{29}$ Laurent Agola, "Combating Money laundering in Tanzania: An Overview of Legal Framework", Journal of African and International Law, 3 (2010), 389.

${ }^{30}$ Difficulty to detect as the definition in section 3 of Money laundering Under Money Laundering Act suggests, Money Laundering to mean engagement of a person or persons, directly or indirectly in conversion,transfer,concealment,disguising, use use or acquisitions of money or property known to be of illicit origin.

${ }^{31}$ Dennis Rumley, Vivian Louis Forbes and Christopher Griffin, Australia's ar'c of Instability: the political and cultural dynamics of Regional Security,(The Netherlands: Springer 2006),204

${ }^{32}$ Idem
} 


\section{International Journal of Social Sciences and Management Review}

Basel Committee on Banking Supervision which prevents the criminal use of the banking system for the purpose of money laundering. ${ }^{33}$

Furthermore, the same year there was United Nation Convention Against Illicit Trafficking in Narcotic Drugs and Psychotropic substance (Vienna Convention). The convention lead to a wider contribution on Anti-money laundering because it imposes the requirement that all states which are the members of the United Nation to introduce money laundering as an offence in their domestic legislations. Article 3 of the convention provides that, the state shall establish money laundering as a criminal offence under the domestic laws. ${ }^{34}$

Tanzania being part of the global community has been affected with money laundering since liberalization of trade, before that most of activities were characterized by the simple theft. ${ }^{35}$ The money laundering activities started in 1980s after decline of the country economy in 1979. At that time the activities of money laundering were at a critical point in which hundreds of people as economic saboteurs who were laundered money in black market, embezzlement of the public funds and corruption were arrested. ${ }^{36}$

During that period Tanzania took initiative of establishing Economic sabotage (Special Provision) Act, ${ }^{37}$ the Act last for three months after being repealed and replaced by Economic and Organized Crime Control Act ${ }^{38}$ to deal with the matter. With development of trade liberalization the offence of money laundering increased within and beyond national borders. Many businessmen with the funds outside the country were allowed to import goods without being asked about the sources of their capital. ${ }^{39}$ Since the money laundering activities perpetrated across the global the Economic and Organised of Crime Control Act was proved to be inadequate since the money laundering criminals were no longer respecting geographical boundaries which cause the investigation to be difficult hence led to the establishment of Mutual Assistance in Criminal Matters Act and Proceed of Crime Act. ${ }^{40}$ These Acts were used to investigate the offence and collecting evidence across the nations.

In 1990 Tanzania started to experience the increase of those activities in the Banking Institutions in which the government enacted Banking and Financial Institution Act ${ }^{41}$ and the Bank of Tanzania $\mathrm{Act}^{42}$ so as to regulate all financial activities conducted in those

\footnotetext{
${ }^{33}$ Dionysios S. Demetis, Technology and Anti- money Laundering: A system Theory and Risk- based Approach, (Cheltenham: Edward Edger Publishing Limited, 2010),12.

34 Ibid., 13.

35 Daniel J. Koenig and Dilip K. Das, International Police Cooperation: a World Perspective,(Oxford: Lexington Books 2001),290.

${ }^{36}$ Rich Stapenhursh and Shar John Kpundeh, Curbing Corruption: toward a Model For Building national Integrity,(Washington D.C: Economic Development Institute of The World Bank 1999),156

${ }^{37}$ Economic Sabotage (Special Provision) Act of 1983

38 The Organized Crime Control Act of 1984 RE 2019

${ }^{39}$ http://204.180.229.21/external/pubs/ft/fandd/2000/06/pdf/kanaan.pdf: Oussama Kanaan, Tanzania's Experience With Trade Liberalization,37 Finance and Development,2000,2 :Liberalization of Trade in Tanzania did promote economic growth, but in absence for any penalties for dubious conduct of business it also intensified money laundering since business people with funds outside the country were allowed to import goods without ever being asked about the source of the capital.

40 The Proceeds of Crime Act of 1991,RE 2019

${ }^{41}$ Banking and Financial Institution Act of 1991

${ }^{42}$ Bank of Tanzania of 1995
} 


\section{International Journal of Social Sciences and Management Review}

institutions. Conversely, despite having many laws to regulate the matter such as Economic and Organised of Crime Control Act and The proceeds of Crime Act, in 2006 Tanzania enacted the specific Act to deal with Money laundering which was Anti Money Laundering Act. ${ }^{43}$

\subsection{LEGAL FRAMEWORK OF ANTI MONEY LAUNDERING IN TANZANIA}

This part discusses the reasons of having Anti money laundering laws while there is an increase of the money laundering. The discussion is based on the provisions on money laundering as provided by various legislations, the role of financial institutions against war of money laundering and international cooperation since the offence based on transnational nature.

Anti Money Laundering laws in Tanzania are ineffective, so there must be deliberate efforts to make the crime of money laundering serious and severe punishment should be imposed so as to curb all activities relating to money laundering within the country. The laws proved to be ineffective since there is a continuation of the offence which is highly detrimental to the economy. With the few cases which I have cited in introduction, it suffices to have the conclusion that Anti money laundering laws are not effective. ${ }^{44}$

Tanzania has a specific legislation aimed at preventing and combating money laundering which is Anti Money Laundering Act $^{45}$ In addition to that law, Tanzania still depends on various laws which existed before which also prohibit money laundering. These laws include the Prevention of Organised Crime Control Act, ${ }^{46}$ and Proceeds of Crime Act. ${ }^{47}$

Despite having those pieces of legislations still the fight against money laundering is not effective moreover in some occasions the offence is committed by public officials ${ }^{48}$ and also the presence of informal economy or unofficial market activities worsen the problem even more. ${ }^{49}$ This facilitated by the nature of economy where money circulations do not necessarily pass through financial institutions hence increases the risk for money laundering activities.

\subsection{The Anti Money Laundering Act and Its Implication to the Offence}

Since the emergence of the crime in 1980s soon after the decline of Tanzanian economy in 1979, there were several legislations dealing narrowly with money laundering as discussed earlier. The Anti Money Laundering Act came recently, in 2006 with the aim of making better provisions for the prevention and prohibition of money laundering in Tanzania but in

\footnotetext{
${ }^{43}$ Anti Money Laundering Act of 2006,RE 2019

${ }^{44}$ Supra,note, 4,5,6,7 and 8

45 Anti Money Laundering Act of 2006,RE 2019

${ }^{46}$ Prevention of Organised Crimes Control Act, [Cap.200 R.E.2002]

47 The Proceeds of Crime Act, Cap 256 of 1991.RE 2019

48 Prosper Karumba and 5 others, CC.147 Iringa Resident Magistrate Court,2009, they laundered TZS 2 billion as the public funds for private benefits.

${ }^{49}$ Friedrich Schneider and Dominick Enste, Shadow Economic around the World: size, causes and consequences, International Monetary Fund Working Paper, 2006, 6: Most of the people in Tanzania conduct their Business outside official market, the market based production of goods and service whether legal or illegal which also add to the country GDP.
} 


\section{International Journal of Social Sciences and Management Review}

reality is not. ${ }^{50}$ The main aspect of the Act which distinguishes it from the previous legislations is the establishment of a Financial Intelligence Unit (FIU) and National MultiDisciplinary Committee on Anti-money Laundering. ${ }^{51}$ The role of the Financial Intelligence Unit is to receive and analyse information concerning the suspected persons. ${ }^{52}$

Following the ineffectiveness operations of the FIU we can see that the organisation is toothless since it deals only with collection and analyses the information of suspected persons ,without juridical mechanism of investigating the offence and finding information in its own as well prosecute those cases concerning money laundering. ${ }^{53}$ Through this we can notice that; still Anti Money laundering Act is not effective to curb the problem. The researcher is of the opinion that; function of this institution (FIU) be reviewed (amended) so as to have judicial force.

Conversely, the National Multi-Disciplinary Committee is responsible in formulating, assessing and improving the effectiveness of the policies and measures to combat money laundering; advise the government on legislative, regulatory and policy reforms in respect of anti money laundering and combating predicate offences; generally, advise the Government in relation to such other matters relating to anti-money laundering and predicate offences. ${ }^{54}$ With this committee also its function is very sophisticated in such a way the Act is inadequate, but still there is no initiative which is taken by the government towards the amendment of the Act. From that situation we can notice these function remains in papers without being implemented.

Under the provisions of the Act a person commits an offence of money laundering if he participates in, associates with, conspires to commit, attempts to commit, aids and abets, or facilitates and counsels the commission of any of the acts, ${ }^{55}$ and ought to know or ought to have known that the property involved is the proceeds of predicate offence. ${ }^{56}$ In the Act the offence appeared to be so complicated in the way local person cannot understand whether the suspected act is money laundering or not.

Furthermore, Anti money laundering laws provides for penalties to individual person as well as corporate bodies for acts of money laundering. The provision of section 13 of the aforesaid $\mathrm{Act}^{57}$ provides for penalties. Banks are required to establish various policies and procedure on how to control money laundering in Tanzania, failure to comply with those procedures and

\footnotetext{
${ }^{50}$ This is due to the fact that; there is a continuation of the offence

${ }^{51}$ Part II of Anti money Laundering Act, 2006,RE 2019

52 Section 4(2) of Anti money laundering Act, provides the Financial Intelligence Unit shall be responsible for receiving, analizing and disseminating suspicious transaction reports and information regarding potential money laundering or terrorist financing received from the reporting persons and other sources from within and outside United Republic.
}

\footnotetext{
${ }^{54}$ Section 9 of Anti Money Laundering Act of 2006,RE 2019

${ }^{55}$ Ibid., Section 12

${ }^{56}$ Predicate offence means and dealing which amount to illicit drug trafficking under the law for the time being relating to narcotic drugs and psychotropic substances;terrorism,including terrorist financing; illicit arms trafficking; participating in an organized criminal group and racketeering; trafficking in human beings and smuggling immigrant; corruption practice;counterfeiting;armed robbery;theft;kidnapping,illegal restraint and hostage taking;smuggling; extortion;forgery; piracy; hijacking and insider dealing and market manipulation.

${ }^{57}$ Anti-Money Laundering Act,2006,RE 2019
} 


\section{International Journal of Social Sciences and Management Review}

policies amount to penalties such as; a fine equivalent to not less than Tsh 1 million in each day of transaction. Moreover, suspension from participating in the inter-bank foreign exchange market operations and prohibited from conducting other financial activities such as; issuing letter of credit, ${ }^{58}$ opening a new branches and suspension of credit facilities of the bank. ${ }^{59}$

Part IV of the Act provides supervision and monitoring of money laundering activities by reporting persons. ${ }^{60}$ These persons normally have the obligations in making sure that they take reasonable step or measures to identify person. This is very important when dealing with political exposed person. ${ }^{61}$ The Act does not explain as to what constitute reasonable measures. This prevents the implementation of the law as to which action constitutes reasonable measures.

Reporting persons are also required to maintain records of all transaction of amount which is under the foreign currencies by the applicant. These records must be kept for minimum of at least five years from the date of completion of the transaction. Nevertheless, the scope of reporting persons is limited to banks and financial institutions, cash dealer, a regulator, customs officer, Commissioners for Oaths, and auctioneers ${ }^{62}$ and therefore other persons who are not listed under the Act have no legal powers to report the crime. The Act also assesses the risk of money laundering activities. Moreover, the officials of money laundering are the ones who participate more to the offence. Can we real manage to curb this offence? Since the agencies for the implementation of the Act engage in the commission of the offence. Can we amend the law and change enforcing organs? This remains for us Tanzanian to decide.

Banks and financial institutions are required to observe the principle of fiduciary and secrecy when dealing with customer not divulging information relating to customers accounts. ${ }^{63}$ Adherence to these principles by banks and financial institution is one of the reasons for existence of money laundering. However, the Anti-money Laundering Act which is yet to be known by many stakeholders in financial sector disregards the duty of secret. ${ }^{64}$

\footnotetext{
58 B.A. Black's Law Dictionary ,West Publishing Company,2004, $8^{\text {th }}$ Edition, Letter of credit is an instrument under which issuer usually a bank, at a customer's request agreed to honor a draft or other demand for payment made by a third party who is a beneficially and it comply with conditions on underlying contract. see also case of Cruickshank V. Westpac Banking Corporation (1989)INLR 11 at 121 (HC), where it was started that letter of credit have a status of their own, the document in common use in the commercial and business world particularly in international and lesser degree, domestic transaction.

59 Bakar R Bakar, International Finance: an arena of level playing field, (Dar es Salaam : Trust Publication ,2007), 141 .

${ }^{60}$ Section 15 of Anti money laundering Act it explain the responsibility of reporting person to verify identification of customer, and section 16 explains the duty of reporting persons to maintain customer records.

61 Politically exposed are defined under section 3 as "foreign individual entrusted with prominent public functions in the United Republic of Tanzania including heads of state or government, judicial or military officials, senior executive of state owned corporation or agencies."

62 The Anti-Money Laundering Act, 2006, section 9.

${ }^{63}$ See section 48 of the Banking and Financial Institution Act of 2006.It provides for fidelity and secrecy: every bank and financial institution shall observe, except otherwise required by law the practice and usage customary among bankers and in particular not to divulge any information relating to customer account.

${ }^{64}$ The Anti-Money Laundering Act, 2006 section 21it say the Act shall have the effect, notwithstanding any obligation as to secrecy or other restrictions, upon the disclosure of information imposed by any law or otherwise.
} 


\section{International Journal of Social Sciences and Management Review}

\section{2 .The Regulation of Illegal Proceeds in Tanzania}

In order to prevent person benefiting from illegal proceeds obtained through money laundering. The parliament of Tanzania passed the Proceeds of Crime Act of 1991 with the aim of confiscating and recovering of the assets from the criminals.

The Act defines money laundering in section $3{ }^{65}$ There are few provisions which deal with money laundering. The only substantive provision which deals with money laundering is section $35 .{ }^{66}$ However, the implementation of this Act is still not effectives since a lot of money laundering activities still happen, but the accused person end up with small punishment and being left with his/her monies. ${ }^{67}$

\subsection{The Prevention of Terrorism Financing in Tanzania}

There is a connection between money laundering and terrorism due to the fact that the launder money sometimes helps to finance terrorism activities. Criminalization of money laundering in Tanzania laid the possibilities of reducing terrorism activities. Following this connection Tanzania enacted, The prevention of Terrorist Act. ${ }^{68}$ There are other incidences associated with establishment of this Act in Tanzania such as 1998 bombing of the US Embassy in Dar es Salaam and threat of a terrorist in Zanzibar, 2002 which has been financed from outside Tanzania by terrorists.

However, the implementation of this Act depend with the cooperation with the US since is the one who facilitate the enactment of the Act, still today there is no law in place for allowing Tanzania to exchange the information with the U.S. Due to that; the problem continue to exist for non- implementation of the law and lack of knowledge on money laundering in aspect of terrorism as a result makes it difficult to deal with the offence.

\subsection{The Banking Regulation and Hawala with Increase of Money Laundering}

Bank is the first institution to detect and report the money laundering hence Tanzania enacted The Bank of Tanzania Act $^{69}$ to deal inter alia with the supervision and prevention of money laundering, through providing mandatory provisions which concerned with record keeping. Under the Act there are provision which concerning with the access to information. ${ }^{70}$ Furthermore, due to the development of technology which extends the

\footnotetext{
${ }^{65}$ The Proceeds of crime Act No.25 of 1991 RE 2019 section 3 it mentions the offence of money laundering, but refer to Anti Money laundering Act.

66 The Proceeds of Crime Act, Section 35(3) stipulates that the Attorney-General, in writing, authorise a police officer to apply to a judge of the High court for (a) an information gathering order requested by foreign country in respect of a foreign specified offences that is a money-laundering offence is respect of proceeds of a serious narcotic offence (b) information about transactions conducted through an account with a financial institution in Tanzania is reasonably believed to be relevant to the proceeding or investigations and (c) the appropriate authority of the foreign country requests the Attorney-General to obtain the issue of a monitoring order the proceeds of crime Act, directing the financial institution to give information to inspector-General of police about transactions conducted through the account.

${ }^{67}$ See again the case of Amatus Joachim the personnel of BoT

${ }^{68}$ The Prevention of Terrorism Act of 2002

69 The Bank of Tanzania Act No.4 of 2006

70 The Bank of Tanzania Act,No.4 of 2006,section 47(1) and (2),section 47(1) it explain the bank shall have the power to access to any oral and documented information including information in computer,books, minutes
} 


\section{International Journal of Social Sciences and Management Review}

relationship between the client and the bank, the Bank of Tanzania Act has the provision in preventing money laundering. ${ }^{71}$ These provisions always are being directed to formal sector of the economy in which the transactions or activities is through bank.

Increase of money laundering in Tanzania influenced by informal sector which is not under the supervision of the banking and other financial institution. Informal financial system in Tanzania leads to money laundering. ${ }^{72}$ For instance, Hawala ${ }^{73}$ which is used by the Tanzanian's communities to collect the vast of money and to distribute it to other people in need as well as unaccounted payments through operators who act as couriers for letter, parcel and money from that transaction it is difficult to be supervised by the bank because there is no record. ${ }^{74}$ Hawala increase money laundering in Tanzania due to the fact that the transfer of money occur in the absence of or parallel to formal banking sector channels, with the expectation of getting high interest. ${ }^{75}$

\subsection{The Banking and Financial Institutions Regulation}

The Banking and Financial Institution Act was enacted in order to provide for comprehensive regulation of banks and financial institutions and the activities of saving, credit co-operative societies and schemes. The underlying objectives of the supervision and regulation of banks and financial institutions of Bank of Tanzania are to maintain the stability, safety and soundness of the financial system and to reduce the risk of loss to depositors. ${ }^{76}$

The banking and financial institution Act also provides a mechanism for supervision, coordination and control of bank and financial institutions. The Act permits the Bank of Tanzania to enter into arrangements for sharing supervisory authorities outside Tanzania. This Act assists the Bank of Tanzania in supervising organizations that operate within Tanzania and in any other country. ${ }^{77}$

\subsection{The Role of Financial Institutions and Money Laundering in Tanzania}

account, cash securities, documents, voutures as well as any other things in the possession or custody or control of a bank or financial institutions or its affiliate, which relate to the business of such a bank or financial institution.

47(2) the bank may carry out at such times as it may consider necessary, an examination of any bank or financial institution in accordance with the provisions of banking and financial institution Act,2006

${ }^{71}$ The Bank of Tanzania Act,No.4 of 2006,Section 48 (6) it say the bank may require banks and financial institutions report to the credit reference databank, other information relevant to their clients' operations including but not limited to information on electronic payment instruments and claques that are returned or refused for lack of funds, fraud or any other information required by the credit reference databank.

${ }^{72}$ Kris Hinterseer, Criminal Finance: the political Economy of Money Laundering in a Comparative Legal Context,(Hague: Kluwer Law International 2002), 1

${ }^{73}$ It refers to money transfers in the formal sector, initial developed due to weak or absence of banking instruments, and it is attractive because of the mechanism;speed,lower transaction costs, cultural convenience,versality potential anonymity contribute to their widespread legal and illegal use.

${ }^{74}$ Wilbert B.Kapinga, "A review of the anti-money laundering system in Tanzania", The Tanzania Law Journal, (2010), 37.

${ }^{75}$ Mohammed El Qorchi,Samuel Munzele Maimbo and John F Wilson, Informal Funds Transfer systems: an analysis of the informal Hawala System,(Washington DC: International Monetary Funds, 2003),47.

76 The Banking and Financial Institution Act, No 5 of 2006 section 31(1)

${ }^{77}$ Ibid., section 35 (2), it say to supervise organizations that operate both within the United Republic and in any other country, the bank may enter into arrangements for sharing supervisory information on a reciprocal basis with the appropriate supervisory authorities within or outside the united Republic. 


\section{International Journal of Social Sciences and Management Review}

Financial institutions ${ }^{78}$ are more affected by money laundering activities. For that reason, bank and non bank institutions take steps to prevent and detect money laundering crimes which endangers their activities as the financial institutions. During the process of controlling money laundering they must consider all process regarding money laundering because each process involves financial transactions. ${ }^{79}$

There are many reasons which push financial institutions to control money laundering which are; first the long term success of the financial sector that depends on attracting and retaining legitimate funds. These funds are attracted and retained for the reason of the nature of products and services, the quality and reliability of the service and the reputation of the centre. ${ }^{80}$ Second, Laundered money is invariably transient in nature. It damages reputation and frightens away the honest investors. Again the money laundering will lower the reputation of financial sector hence facilitate in detecting and prosecuting it. ${ }^{81}$

Many countries believe that, the prevention of money laundering needs participations of financial sector. The reasons behind is that; legislations are not enough to effect the regime of preventing money laundering. An appropriate institutional structure within which the law operates is crucial and specific measures are needed to protect financial sector from being used to launder the proceeds of crime. ${ }^{82}$

The legislations of Anti money laundering are only used for investigation and prosecution process once a crime has been committed, but it can be little in preventing the proceeds of crimes. The engagement of financial sector plays a big role in preventing money laundering in Tanzania since financial sector is the major sector which brings development of the country and all over the world. ${ }^{83}$

The Central Bank of Tanzania which is the Bank of Tanzania (BoT) plays a greater role in ensuring that all financial institutions do apply laws, rules and obligations while performing their functions. However in so doing all financial institution in Tanzania are mandated to adopt and apply banking services policies and procedures to encounter the problem of money laundering.

The researcher is so concerned with the banking since the banks are the main participants in domestic and international payment; they serve as the intermediary for depositors and borrowers and provide financially related products and services. In relation to this a country's Anti money laundering law regime needs to start with the bank, for their crucial role in the financial system. Therefore any bank not having effective Anti money laundering regulations or programs are the one mostly exposed to money laundering, and can easily be exploited by

\footnotetext{
78 Are Institutions that focuses on dealing with financial transactions, such as investment, loans and accept deposits. For instance bank, trust companies, insurance companies and investment.

${ }^{79}$ Wendy Chamberlin, “The Fight Money Laundering”, Electronic Journal , 6 number 2,(2001),24.

${ }^{80}$ Commonwealth secretariat, Combating money Laundering and Terrorist Financing: a model of best practice for the financial Sector, the professions and other Designed Businesses, Second Edition,2006,6.

${ }^{81}$ Ibid., 7.

${ }^{82}$ Financial institutions being vulnerable to money laundering because of its financial economic transaction

83 Brent L.Bartlett, The Negative Effect of Money Laundering on Economic Development; The Asian Development Bank, Regional Technical Assistance Project No.5967,Countering Money Laundering in The Asian and Pacific Region ,May 2002.
} 


\section{International Journal of Social Sciences and Management Review}

domestic and international criminals. ${ }^{84}$ Most of the countries both developed as well the developing countries are concerned with banking in the whole process of controlling money laundering as they form part of financial system.

The financial sector like banks always contributes to prevent money laundering through compliance with the spirit of the Basle principles ${ }^{85}$ and adherence to the FATF financial sector recommendation. ${ }^{86}$ Their contributions normally based on knowing customers, keeping necessary records, cooperation with the enforcement agencies through reporting suspicion of money laundering and provision of information which are necessary. ${ }^{87}$

In 1988, a new global standard was introduced in respect to financial institutions which imposes the duty of transparency and requires the states to relax on the duty of secrecy by the bank which is a strong mechanism in controlling money laundering by the financial institutions not only within the country but also all over the world. ${ }^{88}$

Financial institutions like banks not only act as reporting agent but also control money laundering, banks represent an important actor within the Anti money laundering. The financial institutions are involved in the battle against money laundering in a three folds manner first they are a commercial institution aiming to present themselves as a reliable and trustworthy towards shareholders. ${ }^{89}$ This implies implementation of anti money laundering and compliance policies to show outside world that they are taking these matters seriously. Second the financial institution also acts as an inspection agent to monitor and verify transactions of their customers and employees. Financial institutions are put in a position that may lead to conflict of interest between their obligations towards the authorities on the one hand and responsibilities towards client on the other. Third, bank themselves are regulator as well as potential offenders. ${ }^{90}$

Financial institutions such as banking and non-banking are the heart of economy in Tanzania. These institutions allow for the concentration of capital resources from saving in abroad as well as efficient of allocation of such resources to investment projects that generate sustained economic development. Money laundering practices erode financial sector and loss of the customer trust which is the fundamental to the growth and survival of the financial institutions so this money laundering such as fraud and corruption is the major obstacle. ${ }^{91}$

\footnotetext{
84 Pierre-Laurent Chatain,John Mcdowell,Cedric Mousset Paul Allan Scott and Emile Van Der does De willebois, Preventing Money Laundering and Terrorist Financing: a practical guide for Bank Supervisors, (Washington D.C: World Bank,2009),7.

85 The Basel Committee on Banking Supervision 2001.Customer Due Diligence for Banks

86 FATF is an intergovernmental organisation established by G7 countries in 1989, with the purpose of controlling money laundering and terrorism.

${ }^{87}$ FATF is an intergovernmental organisation established by G7 countries in 1989.

${ }^{88}$ Mary Michelle Gallant, Money laundering and the proceeds of Crime: economic crime and civil remedies, (Chaltenham:Edward Elgar Publishing Limited,2005),14:As it applies to Anti Money Laundering Act of 2006.

${ }^{89}$ Antoinette Verhage, The Money laundering complex and the compliance industry, (New York: Routledge,2011),5.

${ }^{90}$ Idem

91 Brent L.Bartlett, The Negative Effect of Money Laundering on Economic Development for the Asian Development Bank Regional Technical Assistance Project No.5967, Countering money laundering in the Asian and Pacific Region, Economic Research Report, May 2002
} 


\section{International Journal of Social Sciences and Management Review}

However, while other banks in most of the countries concentrate in preventing money laundering so as to raise the business reputation for the development of their countries, in Tanzania this is not the case due to a lot of scandals which associated with money laundering and wonderful enough there is participation of the Bank of Tanzania. ${ }^{92}$

From this discussion we can see the problem of money laundering in Tanzania is caused by the enforcing agencies like those who works in financial institutions since themselves engage in money laundering. This shows how the banking sector is ineffective in this aspect.

Furthermore, it is suggested from the field that the major control is through adopting the policy on Anti Money Laundering and Know Your Client / Customer (KYC) procedures that make possible to deal with the matter. ${ }^{93}$ In case of the Access Bank Tanzania, in order for them to prevent criminals from using the banks products and services for the mentioned problem the bank has established a policy on Anti Money Laundering and the fight against financing terrorism and follows special procedures. It is each employee's duty to know and apply these rules and regulation at any moment during his or her daily work ${ }^{94}$ and they are available to every employee; each employee is responsibility to ensure adequate familiarity with this policy.

However, this aspect is very difficulty since even the bank employees lack this knowledge of money laundering due to lack of training programme. Following that they cannot deal with clients to discover the problem of money laundering.

\subsection{International Cooperation in Fighting Money Laundering}

Though it has been specified under the title "Money Laundering and Legal Framework of Anti Money Laundering in Tanzania", as a domestic legal framework, the international cooperation is very important specifically on international law in which Tanzania is a part since money laundering distorts business decisions, increases the risk of banks failure which had the impact all over the world as well takes control of economic policy away from the government. From the explanation above it is important to discuss on the international cooperation since it assists the individual country in proper implementation of the laws.

Moreover, the development of financial industry and growth of banking system operating in different jurisdictions makes it important to have International cooperation between authorities in different countries. Since there is an increase of sophisticated methods used to move illicit funds through financial system across the globe, the need for establishing various

\footnotetext{
92 International Monetary Fund African Development, United Republic of Tanzania: third review under the policy support, Instrument -staff Report,2008: a special audit of the external payment arrears (EPA)account at the Bank of Tanzania conducted by Ernst and young company on behalf of the Controller and Auditor General (CAG) which was conducted in December 2007.After completion of the audit was a structural benchmark under PSI. The audit identified serious improprieties in the management of the account. The central funding released by the government in January 2008,were that a total of Tsh 133 billion (about US dollar 113million)was paid under EPA scheme during 2005/06 (July-June) to 22 local companies based on fraudulent documentation or without any supporting documentation. Upon receiving the report, the governor of the Bank of Tanzania (BoT) was dismissed.

93 Access Bank Tanzania, National Bank of commerce and Exim Bank in Dar -Es -Salaam

${ }^{94}$ Access Banks policy on Anti money laundering and know your client procedure.
} 


\section{International Journal of Social Sciences and Management Review}

international regulations to curb problem is very important ${ }^{95}$ Tanzania is not isolated country since it operates their financial activities in cooperation with other states.

\subsubsection{The Control of Illegal Drugs Trafficking and Prevention of Money Laundering}

Since illegal drugs trafficking are associated with two or more states then the cooperation among states is vital. This covered by Vienna Convention ${ }^{96}$ under international arena. To comply with their obligations under the Convention, the parties are required to take such legislative and administrative measures which criminalizes all forms of narcotics trafficking, drug-related money laundering and provides for the confiscation of property derived from such drug-related crimes. Article V of the Vienna Convention details the obligations of the parties to seek confiscation of drug trafficking and money laundering proceeds, as well as the instrumentalities used to commit such offences. ${ }^{97}$ It also requires each party to provide assistance to another country by identifying, tracing, seizing, freezing, or confiscating of any property or proceeds which were derived from, or used in, drug trafficking or drug money laundering and which may be located in their country. ${ }^{98}$ In Tanzania after ratification of the convention created obligations, upon ratification, to criminalize and extradite money laundering.

For instance in 2003,Tanzania helped Zambian state by arresting two Zambian nationals with a container carrying $1836.3 \mathrm{~kg}$ of cannabis valued at Tsh 3.3 billions, which is a lot of money. ${ }^{99}$ Through this example we can see how international obligation is important in preventing money laundering.

\subsubsection{The Regulation of International Standards in Fighting Money Laundering}

The FATF ${ }^{100}$ is an international working group whose purpose is the development and promotion of policies to combat money laundering. These policies aim to prevent such proceeds from being utilized in future criminal activities and from affecting legitimate economic activities. The FATF requires each country to take necessary measures to criminalize money laundering for all serious crimes. The determination of what constitutes

\footnotetext{
95 Pierre-Laurent Chatain,John MacDowell Cedric Mousset, Paul Allan Schott, Emile Van Der, Does De Willebois, Preventing Money Laundering and terrorism financing a Practical Guide For Banks Supervisors,(The World Bank: Washington D.C 2009)160.

${ }^{96}$ United Nation (UN) Convention Against Illicit Trafficking in Narcotic Drugs and Psychotropic Substance 1988

${ }^{97}$ United Nation (UN) Convention against Illicit Traffic in Narcotic Drugs and Psychotropic substance 1988(Vienna Convention), Article V (2), It emphasis that each party shall also adopt such measures as may be necessary to enable its competent authorities to identify, trace, and freeze or seize proceeds ,property ,instrumentalities or any other thing for the purpose of confiscation.

${ }^{98}$ Ibid., Article V (3) Each party shall empower its courts or other competent authorities to order that bank, financial or commercial records be made available or be seized. A party shall not decline to act under the provisions of this paragraph on the ground of bank secrecy.

99 Eugene E Mniwasa, Detection and Suppression of Money Laundering in Tanzania: Charles Goredema, Tackling Money Laundering in East and Southern Africa: An Overview of Capacity, Issue 108(South Africa :Institute For Security Studies, 2004), 46

${ }^{100}$ FATF is an intergovernmental body formed by G7 countries in 1989, for the purpose of developing and promoting national and international policies to combat money laundering and terrorist financing. One of the first tasks of FATF was to develop Recommendation 40, which set out the measures to the national government to implement anti money laundering programs.
} 


\section{International Journal of Social Sciences and Management Review}

serious crimes and what will be designated as money laundering predicate offences is left to each country to decide. ${ }^{101}$ Tanzania recently undertook to implement the international Financial Action Task Force's recommendations on money laundering. ${ }^{102}$ FATF has became the most important international body in terms of formulating anti money laundering policy and mobilizing the world to become aware of the complex issues involved in countering this sophisticated form of criminality. ${ }^{103}$

These recommendations are also more useful in improving the national legal systems, but the problem which faces the recommendation is based only with financial institution unlike other economic activities. Financial institutions acts as a core of prevention of money laundering as stated by the Pecchioli as follows;

"The common thread underlying these recommendations is the view that financial institutions are the key element in the detection of illicit transactions given their unique function in a country's payments system and in the collection and transfer of financial assets" 104

With this weakness of FATF makes even the establishment of the country laws in fighting money laundering to have a problem of non recognised person to report the offence. Hence the implementation of the law becomes difficult.

As we have discussed in this chapter, the legal framework of money laundering in Tanzania is not effective since there are many continuation of money laundering activities and even the penalty is very low when the perpetrator in convicted with the crime, following that; in order to build strong financial institutions and money laundering elimination there must be effectiveness of legal framework in one country which goes hand with hand with international standards of controlling money laundering.

\subsection{ANALYSIS OF MONEY LAUNDERING AND ITS IMPACTS TO THE TANZANIAN ECONOMY}

Money laundering has direct negative impact on economic growth as we have seen throughout our discussion. ${ }^{105}$ Tanzanian economy also falls under the same umbrella. Since the great part of the economy of the country remains in the hands of few people who are criminals hence it affects Gross Domestic Product (GDP) of the country. This paper focuses

101 Paul Allan Scott, Reference guide to anti money Laundering and combating the financing of terrorism, (Washington D.C: World Bank 2006),1-3.

102 Tanzania is a member of the Eastern and Southern Africa Anti-money Laundering Group (ESAAMLG), which seeks to intensify efforts to implement the revised 40 recommendations of the Financial Action Task Force.The 40 recommendations are available at http://www.fatfgafi.org/documents/28/0,3343,en_32250379_32236930_33658140_1111,00.html accessed on 5 June 2011.

${ }^{103}$ William C. Gilmore, Dirty money: the evolution of money laundering counter-measures, (Belgium: Council of European publishing, 1999), 79.

104 Ibid., 86

105 Brent L.Bartlett, Research Paper Report: The Negative Effect of Money Laundering on Economic Development,2002: http://www. Adb /document others/orgc-toolkits/anti-money-laundering/documents/money laundering-neg-effects.pdf. 


\section{International Journal of Social Sciences and Management Review}

on money laundering assessment and its impact in the economy and the challenges facing the government of Tanzania in controlling the problem under the existing legal framework.

\subsection{Damaged Financial Institutions}

Money laundering affects financial institutions since it leads to banks risks such as liquidity risk through withdrawal of money, investigation cost and penalties. ${ }^{106}$ Liquidity risk happens when the laundered money being withdrawn from the bank. This risk leads the bank failure to meet repayment commitment on time as a result can run insolvent. This situation can be elucidated in the case of Advocate Mwale who is involved in 13 counts of money laundering in which large amount of money laundered obtained from National Bank of Commerce in Moshi Branch Tsh 5.4 billion and National Micro-Finance Bank Tsh 243,260,000. ${ }^{107}$ In this case also a large amount of Tsh 3 billion were found on his bank account, if the accused withdrew this amount from the bank, the bank can undergo financial deficit since the transaction of large amount of money needs time.

As we know the reputation of the financial institutions is of great value for their survival since the public needs trust from the institutions so as to be assured. If the reputation is being damaged through engaging in money laundering, it can be impossible for the member of the community to invest their money in those banks. ${ }^{108}$ The bank or financial institution must have confidence so as to attract investors both home and abroad. And once the financial institutions lose the confidence the investors may be discouraged to invest since many investors are not risk takers. ${ }^{109}$

Conversely, financial institution also can weaken its reputation to the community at large as a result it may lose customers. Once the banks or other financial institution lose customers, they can run insolvency and may also lead to the decrease of trust to local and foreign investors, as it happened in the Bank of Tanzania and five other banks in the case of External Payment arrears. External Payment Arrears (EPA) account held at the Bank of Tanzania which caused the loss of SS\$ 131 billion as a huge amount of money to Tanzanian economy. This highly affects the economy since the financial institutions which are expected to strengthen the country economy are sometimes involved to launder money as explained above. Therefore illicit economies such as all activities associated with money laundering create negative impact in the country economy. ${ }^{110}$

From this finding we can get a picture how financial institution of the country can be affected as a result of money laundering caused by either financial institutions themselves or their customers. The financial institutions in most developing countries like Tanzania as the centre

\footnotetext{
${ }^{106}$ Paul Allan Scott, supra note 35,IR-4

${ }^{108}$ Edward B.Flowers, Thomas P. Chen and Jonchi shyu, Interlocking Global Business System: the restructuring of Industries, Economic and Capital Markets,(United State of America: Greenwood Publishing Group Inc 1999), 179.

109 Paul Kennedy, "Watching The Clothes Go Round: Combating The Effect of Money Laundering on Economic Development and International Trade", Currents International Trade Law Journal,12(2003), 142.

${ }^{110}$ Alex Arieff, Martin A. Weiss, Vivian C. Jones: The Global Economic Crisis: Impact on Sub-Saharan Africa and Global Response: Congression Research Service,2010,6:http://www.fas.org/sgp/crs/row/R40778.pdf.
} 


\section{International Journal of Social Sciences and Management Review}

of the economy, once these are affected with the laundered money they lose trust to the community within the country as well at international aspect through foreign investors.

\subsection{Inflation}

Inflation is the situation whereby there is an increase of price of goods and services. Money laundering causes inflation in the country since laundered money which backed into the economy is not backed by the real Gross Domestic Product (GDP) hence creates negative impact on the supply of money. ${ }^{111}$ The laundered money affects the supply of money since large amount of money circulating in the hands of society which cause an increase of the price of goods and services.

\subsection{The Distortion of Competition Market in the Country}

Competition market cannot work in the country where there are many activities of money laundering because it operate when there is a transparency of the information, several firms in the market with the same product and absence of the barriers to enter into the market. But with the activities of money laundering competition market is distorted in the sense that; the businessmen always possess economies of scale which cannot allow small firms to operate in the market due to high production cost as well there is information asymmetry because of illegal proceeds. ${ }^{112}$ Furthermore, the price of their products can be below production cost which also automatically the small firms which operate under competitive basis can run out of the market. These happen due to the characteristic of customers of minimizing the cost and maximize the profit in all aspect of consumption.

From the above explanation we can see how money laundering has effect in the whole process of competition, since those who have laundered money are stronger than their competitors. ${ }^{113}$ Money laundering distorts economy owing to the fact that money launderers do not care about profit generations from their investments but they are interested in protecting their proceeds and disguising their illicit origin. This usually impairs economic growth through casing harm to private sector development because the investment decisions do not follow common commercial considerations. ${ }^{114}$

Furthermore, normally those who laundered their money cannot compete with other small person since others do not pay tax to the government. This situation is a critical issue in Tanzania as happened in cases of Justice Lumina Katiti and 5 others, ${ }^{115}$ and Justice Katiti and 4 others $^{116}$ these cases are pending in the court of law whereby justice Katiti and others used to launder money in their business and avoid paying tax up to the amount Tsh $4,141,043,113.03 /=$.With this spirit they can do whatever they like in the business hence lead to unfair competition. In the situation there would be no equality in business.

\footnotetext{
${ }^{111}$ Charles Tive,419 Scam: Exploits of the Nigerian Con Man,(Lincoln: United State of America 2006),61

112 Eugene Buttigieg, Competition Law: safeguarding the Customer Interest: a comparative Analysis,(Netherlands: Kluwer Law International,2009),13

${ }^{113}$ It is important to note that the people who are dealing with the transaction involving money laundering are strong economically hence make very difficult to trace and arrest them.

114 Guillermo Calvo, Arturo Galindo,Alejando Izuquierdo and Alejandro, Microeconomic and social progress in Latin American Development Bank, (Washington D.C, 2004), 242

115 CC. No 152 of 2010 Kisutu Resident Magistrate Court

116 CC.No. 149 of 2010 Kisutu Resident Magistrate Court
} 


\section{International Journal of Social Sciences and Management Review}

However, on the other hand money laundering can have positive effect to the economy because those who laundered their money invest in different sectors of economy like hotel, agricultural project, building houses which can lead to employment on the country as well government revenue by collecting tax in those investments. Though is dirty money it may lead to economic growth of the country if it is used for lawful activities. For instance in Tanzania those who launder money and invest in real estate or other long term investments which boost the growth of country economy. However, few people who launder the money in Tanzania involve in a long term investment, most of them involved in a short term investment such as; buying luxurious goods like cars which are highly detrimental to the domestic economic activities of the country like unemployment as evidenced in the case of Advocate Mwale who spent a lot for luxurious goods including buying of posh cars such as land rover, Discovery SUV and BMW. ${ }^{117}$

These activities of money laundering really affect Tanzanian Economy to a large extent. According to a report of US-based financial watchdog, Tanzania leads the list of the East African Countries that have lost US dollar 8.9 billion due to money laundering within these recent years hence the country remain to be poor. ${ }^{118}$

\subsection{Corruption and Money Laundering in the Economy}

Corruption is a criminal offence which is associated with giving or receiving bribe. ${ }^{119}$ In Tanzania the corrupt acts are explained in section 15 of The Prevention and Combating of Corruption Act. ${ }^{120}$ It implies also the use of public position for illegitimate private gains. ${ }^{121}$ The corrupt money need to be concealed in terms of money laundering. Furthermore, corruption contributes to laundering of money from other kind of crimes through payment of bribes to person who is responsible for operation of anti money laundering system. On the other hand we can say that money laundering is a wider concept in which embodies many crimes including corruption. ${ }^{122}$ Corruption is a crime which has its ultimate aim of enjoying proceeds of crime. For example grand corruption is one of the forms of laundering activity which is likely to take place in an attempt to disguise the illegitimate source of wealth. ${ }^{123}$

${ }^{117}$ Daily News, Tanzania, Wednesday, $10^{\text {th }}$ August 2011

119 Richard K. Gardon, Laundering the Proceeds of Public Sector Corruption, Research paper series in legal studies, Working Paper, ( March 2009),5

120 The Prevention and Combating of Corruption Act Cap 329

121 Amatus Joachimu Liyumba V.R. The High Court of Tanzania(Dar es Salaam District Registry) At Dar es Salaam, Criminal Appeal No.56 of 2010,In this case the appellant was convicted for two years imprisonment before Magistrate court for the offence of Abuse of office contrary to section 96(1) of the Penal Code in this count ,the appellant being a person employed in the public service as a Director of Administration and personnel in the Bank of Tanzania(BOT) abused the authority of his offence by arbitrarily undertaking major decision in the construction project of B.O.T ten Mirambo office Extension, the decision prejudiced the right of the Board of Director of Bank of Tanzania. Furthermore, other count which the appellant faced is occasioning loss to a specified authority contrary to section 284(A) (1) of the Penal Code, It was alleged that government of Tanzania Suffer loss of USD 153,007,715.71 or an equivalent to Tsh.221,197,299.95/=.The High court upheld the decision of the Magistrate Court.

122 Peter Gottschalk, Policing Financial crime Intelligence Strategy Implementation, (Boca Raton: Brown Walker Press, 2009), 75.

${ }^{123}$ Anti Money Laundering Act of 2006,section 12 provides the offence of money laundering associate with, if a person engage directly or indirectly, in transaction that involves property that is proceeds of a predicate 


\section{International Journal of Social Sciences and Management Review}

Money laundering laws are ineffective in whole aspect of controlling corruption and other crimes for the economic development in Tanzania. ${ }^{124}$ Most of crimes in Tanzania which are associated with the money laundering pose difficulties in investigation because of the duty of confidentiality. ${ }^{125}$ Tanzania being a Former British colony follows principle of confidentiality which was established in the case of Tournier $v$ National Provincial Bank. ${ }^{126}$ Although Part $\mathrm{VI}^{127}$ provides supervision, coordination and control to banks and financial institutions, but in practice is not the case in Tanzania hence corruption still exist to a large extent.

Corruption in Tanzania is a big problem which causes underdevelopment of the country. ${ }^{128}$ The government officials are the ones who concentrate much to develop this offence of money laundering. This problem is critical in Tanzania, for instance in 2008 there was a grave corruption on the side of the government which caused the president Kikwete to reshuffle the cabinet in February on that occasion the Prime Minister Lowasa resigned. Likewise the governor of the Bank of Tanzania David Balali was left the post for his involvement in dubious payments in the range of some US dollar 200 to US dollar 800 million from the Bank's commercial external debt account. ${ }^{129}$ Through this data we can see how large the problem continues in Tanzania while we have some pieces of legislations to govern the matter.

Furthermore, even the officials in the regions and district levels commit the offence through depriving the rights of others. For instance district secretary Lotti Ole Mailuti faces the charge of over corruption and totally destroys all the documents that could be used as the evidence. The same person accused of collecting 2 million through illegal procedure. ${ }^{130}$ All the cases which involve the big amount of money always the investigation take so long time and sometimes end up with no charge. From this situation we really need to have laws with proper implication since the persons who administer the laws go contrary to the law. There is a need of restructuring the whole agencies which deals with the offence associated with money laundering so as to allow effective implementation of the law.

Additionally, there is other corruption in Tanzania which is called petty corruption that affects country economy. Petty corruption is identified as corrupt acts by public officials who seek or receive bribes because of their low income in relation to standard of living. Those

offence while he know or ought to have known that the property is the proceeds of a predicate offence; A grand corruption fall under predicate offence and normally pass through three stage of money laundering.

124

125 As provided by different legislations like Banking and Financial Institutions Act of 2006, Section 48.

${ }^{126}$ [ 1924] I K.B.461:The case established the duty of confidentiality, but also provide four exceptions; when disclosure required by law, when banker owes duty to public, in the interest of bank and lastly at the customer demands. This exception can work properly in developed countries not in developing countries due to low level of technology.

${ }^{127}$ Banking and Financial Institution Act of 2006

128 Rich Stepenhurst and Shar John Kpundeh, Curbing Corruption: toward a model for building national integrity, Washington D.C: World Bank,2004),158.Corruption contribute to economic stagnation and helped to concentrate power and wealth in the hands of few people. Corruption also led to a crisis in public administration in Tanzania. It has distorted public decision making and transferred responsibility for the government priorities and spending away from vested public authority individual civil servant or politician and their corrupt sponsors.

${ }^{129}$ Kjell Haunevik, Aida C Isinika, Tanzania in Transition: From Nyerere to Mkapa, (Dar es Salaam: Mkuki na Nyota Publisher Limited, 2010),270.

130 The Guardian,Tanzania,Tuesday $9^{\text {th }}$ August 2011 


\section{International Journal of Social Sciences and Management Review}

corruptions include bribes in registrations of children in schools, patient at hospital so as to receive treatment, trade officers solicit and accept bribes from businessman as well as land officials for the allocation of land. ${ }^{131}$

However, this corruption looks like small corruption but it affects the economy since it prevents the provision of social services to the society which is the good sign for the development of the county. When the country provides good service it is an indicator of development.

According to PCCB investigations, the problem of corruption is still critical in Tanzania. In year 2010-2011 investigated cases range 2,258 of which 598 cases completed and 399 cases still in court and 1,261 cases still in investigation. ${ }^{132}$

However, there is a clear distinction in other countries between corruption and money laundering but in case of Tanzania the corruptions activities are being considered as money laundering offence and follow under the predicate offence under the Anti Money laundering Act. See statistic data in Appendix on how corruption affects Tanzanian economy. ${ }^{133}$

\subsection{Tax Evasion and Money Laundering in Tanzanian Economy}

Tax evasion implies the wilful of the taxpayer not to disclose income while the law requires the taxpayer to pay tax. ${ }^{134}$ In Tanzania tax evasion is considered to be money laundering since the person obtains illegal proceeds. These are many cases in regarding to tax evasions which follow under umbrella of predicate offence. ${ }^{135}$ Tax evasion is also associated with the same mechanism of secrecy like money laundering. ${ }^{136}$ Tax evaders conceal assets or do not fully declare the income that they have lawfully earned.

Similarly the ultimate objective of money laundering is to disguise the source and sometimes the nature of wealth. The proceeds from unlawfully activities are generally not reported to the tax authorities and tax evasion often necessitates financial transactions. ${ }^{137}$ The whole process of tax evasions leads to the negative impacts to Tanzanian economy. For instance in the case

131 Jorge Martinez-Vazquez, Javier Arze del Granado and Jameson Boex, Fighting Corruption in the Public Sector, (Elsevier,2007),200.

132 The Guargian,Tanzania $24^{\text {th }}$ June, 2011

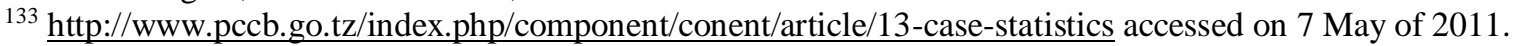

134 Luoga F.D.A. Makinyika, A sourcebook of Income Tax Law in Tanzania, DUP (1996) limited, (Dar Es salaam: DUP (1996), 2000),35.

135 R.V. Donati s/o Thadei@ Labila, In the Resident Magistrate's Court of Iringa at Iringa, Criminal Case No.8 of 2007.In this case the Thadei was charged with fraudulent evasion of tax contrary to section 47(1) (3) of Value Added Tax,Cap.148.R.E 2002,Donati in 2007, fraudulently and with intent to evade tax a total of Tanzanian Shillings two hundred fourteen million three hundred and seventy five thousand five hundred and ninety five only (Tshs.214,375,595.00) had imported sugar from Malawi under tax exemption purporting the same was for charitable purpose, the fact he knew to be false. Moreover, the other count in which the Thadei is charged with was fraudulent evasion of import duty contrary to section 203 (e) and 201 of the East African Community Customs Management Act no.1 of 2005.Currently the case is pending for decision before Magistrate court At Iringa.

136 OECD ,Money Laundering Through the Football sector, FATF Report July 2002,28

${ }^{137}$ Donato Masciandano, Global Financial crime: terrorism, Money laundering and off shore centre, (England: Ashgate Publishing Limited, 2004),181: Money Laundering Through the football Sector, OECD, FATF Report 2002,28 . 


\section{International Journal of Social Sciences and Management Review}

of R.V Donati s/o Thadei which made Tanzania lose Tsh 214,375,595.00. Tanzania should take this offence more seriously including cancellation of business licence if possible since most of the people commit this offence and end up only paying small amount of money.

\subsection{Money Laundering and Macroeconomic Stability in Tanzania}

Macroeconomic ${ }^{138}$ has been affected by money laundering, as it causes loss of welfare and many negative cross border externalities. It can distort allocation of economic resources and distribution of wealth in the sense that the economy of the country possessed by few people. ${ }^{139}$ It is necessary to talk about money laundering in connection with macroeconomic because macroeconomic deals with the total income in a nation while the income can be contributed with both legal and illegal activities. ${ }^{140}$

Most of the people in Tanzania depend on agriculture for $80 \%$ which help to increase the income of the country, and the remaining $20 \%$ engage in other activities and all activities are affected by money laundering. ${ }^{141}$ It is the truth that most money laundering in Tanzania is conducted by the public officials who are high class unlike the lower class. Macroeconomic stability of the country depend on the legitimate funds unlike illegitimate funds, but in Tanzania the situation is verse versa since even production of notes involves money laundering hence fake money under circulation which highly affect macroeconomic stability of the country. ${ }^{142}$

There is no clear statistic of how macroeconomic be affected by money laundering in Tanzania since there are many underground economic activities which are facilitated by money laundering and affect macroeconomic. However, this aspect being ignored by most countries including developed and developing countries. The report adopted by the Commission of the European Communities in 1998 states;

"It is concluded that although difficult to measure, the magnitude of the sums involved and the extent of the criminal activities that generate (criminal) income have implication for both domestic and the international allocation of resources and macroeconomic stability. Although the IMF report there is currently no theoretical literature on the macroeconomic effect of money laundering, indirect macro-based empirical research and related studies of crime and the underground economy; coupled with the pervasive role of money laundering in

\footnotetext{
${ }^{138}$ It concerns with the study of the behaviour of economy as a whole. It examines the overall economy of a nations employment, price and foreign trade.

139 Saresh Padmalatha, Management of banking and Financial Services, (New Delhi: Dorling Kindersley Pvt Limited,2010), 107.

${ }^{140}$ Peter J.Quik,Money Laundering: Muddying the Macro economy,(Finance and Development,1997),8.

${ }^{141}$ Sarris,H,A and Brink,V.R,Economic policy and Welfare During Crisis and Adjustment in Tanzania, (New York: University Press,1993).

142 R.V Simon E. Jengo and 2others of 2010:The cases concerning printing bank note and causes the government the loss of Tsh. 104 Billions
} 


\section{International Journal of Social Sciences and Management Review}

illegal activity, suggest that widespread to exert an independent impact on the macroeconomic". ${ }^{143}$

This is evidenced by lack of comprehensive money laundering policy and procedures in the Bank of Tanzania (BoT). The controller and Auditor General (CAG) saying that bank is incapable of controlling money laundering since it lack integrated policy on the matter. ${ }^{144}$ The bank also has no guideline in place covering all relevant areas such as; directorate, foreign department, banks branches and deposits monitoring units. ${ }^{145}$ Following this discussion, there is no statistic which shows how macroeconomic have been affected by money laundering, since BOT regulate all financial institutions in the country. The officials are supposed to be careful in this aspect because it can lead to underdevelopment or cause an increase of poverty in the country.

\subsection{Money Laundering in Capital and Trade Flow in Tanzania}

The criminal activities affect capital and trade flow in every society. However, the most relevant aspects are related to economy, finance and policy formulated by the society. The economic financial aspects is basically affected in three ways ${ }^{146}$ that is, it reduces the resources of the formal economy, investing capitals contrary to economic expectations and disregard achieving normal profit. This is because illegal funds are in general invested for speculation, accumulation or concealment. Therefore this causes a drop in the rate of international economic growth and may even damage the regular functions of financing capital markets.

Furthermore, findings suggest that the inflow or outflow of funds of criminal origin may adversely affect a country's market stability with three major consequences. The inflow and outflow of funds laundered distort capital and trade in Tanzania through changing in variables such as interest rate, exchange rate, the price of the properties, liquidity and quotations of shares and debts instruments. In addition to the findings the inflow or outflow of money laundered distort capital and trade flows by decreasing level of transparency, soundness, confidence and reliance on financial markets. ${ }^{147}$

Regarding to the invisible economy which constitutes money laundering can disable the capital flow and exchange rates. It can have an adverse influence on banking system and financial services market. The bank has an important function in the international trade hence it affect the movement of capital. ${ }^{148}$

\subsection{The Challenges in Controlling Money Laundering in Tanzania}

\footnotetext{
143 Valsamis Mitsilegas, Money Laundering Counter-measures in the European Union: a new paradigm of security Governance versus Fundamental legal Principles , (Hague :Kluwer Law International ,2003),187.

${ }^{144}$ Wilfred Edwin, BOT lacks ,Capacity to trace dirty money.

Available at http://www.theeastafrican.co.ke/news/-/2558/599204/-/index.html? Accessed on 13 $3^{\text {th }}$ July 2020.

145 Ibid.

${ }^{146}$ Manager Accountant, National Bank of Commerce, Dar-es-Salaam, Telephone Interview,20 ${ }^{\text {th }}$ July 2020

${ }^{147}$ Branch manager, National Bank of Commerce, Dar-es-Salaam, Telephone Interview, $7^{\text {th }}$ July 2011.

148 Jonathan Reuvid, Jim Sherlock and Devid Sherlock, International Trade: An Essential Guide to the Principles and Practices of Export, (New Delhi: Replica Press Pvt Limited, 2010),348.
} 


\section{International Journal of Social Sciences and Management Review}

There are many challenges associated with controlling money laundering in Tanzania due to the fact that money laundering is the crime which is committed in a secrecy basis hence makes it difficult to control in other areas. In Tanzania and all East African governments, the record on enforcing the Anti money laundering legislations that do exist is ineffective, despite of having much legislation in preventing money laundering.

Despite the fact that all nations pursue sustained economic growth, their success towards money laundering control, findings show that Tanzania being the country with the framework of anti money laundering, and combating financing terrorism can have powerful influence on preserving a nation's financial stability. Thus the strengthening of Anti Money Laundering and Combating financing of Terrorism is of vital to individual nation and international community. However, all their successes on preserving depend on nation's financial stability, but still Tanzania has challenges on the effectiveness of controlling the problem.

\subsubsection{Electronic Banking}

E-Banking is online banking and sometimes known as electronic fund transfer (EFT), it means transfer of funds, other than a transfer of originated check, draft or similar paper instruments which is initiated through electronic terminal, telephonic instrument or computer or magnetic tape so as to order instruct or authorise a financial institution to debit or credit an account. It includes but not limited to, point of sale transfer, automated teller machine transactions, direct deposits or withdraw of funds and transfer imitated by telephone. ${ }^{149}$ The electronic banking is more exposed to operational risk when the banks integrate their electronic banking system with their existing legal systems, the information technology infrastructure of service providers and with their customer access device. ${ }^{150}$

Funds transfer systems are classified as either paper based or electronic depending on the mode of communication of payment instructions. In paper based funds transfer system the paper with payment instruction is physically transferred from one bank to another. To the contrary, in electronic funds transfer system the payment instruction is made electronically such as by magnetic tape, disc or telecommunication link. ${ }^{151}$

Previously, in Tanzania the relationship between the bank and the customer is that of the debtor and a creditor. ${ }^{152}$ Once the money is deposited into the bank, it becomes banker's money subject to payment to the customer on demand during working hours and at the branch where the account was opened. This principle was lucidly articulated by Atkin, LJ in the following terms:

"The bank undertakes to receive money and collect bills for its customer's account. The proceeds so received are not to be held in trust for the customer, but the bank borrows the proceeds and undertakes to repay them. The promise to repay is to repay at the

\footnotetext{
149 James Brook, Payment System: Examples and Explanations, (New York: Aspan Publishers 2010), 403.

${ }^{150}$ David B.Audretsch,paul J.J Welfens, The new economy and economic growth in Europe and the US, (Berlin: Springer-Verlag,2002).

${ }^{151}$ Penn and Shea, The Law Relating to Domestic Banking, (London: Sweet and Maxwell 2003) ,67

${ }^{152}$ Libyan Arab Foreign Bank v. Bankers Trust [1989] Q.B 728,748
} 


\section{International Journal of Social Sciences and Management Review}

branch of the bank where the account is kept, and during banking hours." 153

Following technological development in information and communication such as the use of computers whereby bank branches are connected, the requirement of lodging the demand for payment at the branch where the account was opened and during working hours has become unnecessary. The development of technology in Tanzania leads the offence of money laundering to increase. ${ }^{154}$ The problem increases due to lack of technology and non existence of laws which goes with development specifically laws which cover only electronic banking in Tanzania since even Anti money laundering Act does not provides for electronic transaction.

Furthermore, Money remittance system is a financial system which moves funds for individuals or entities through a dedicated network or through the regulated banking system. For instance, fund transfer services that lack clear regulatory framework are mobile phone payment schemes like M-pesa and Z-pesa. ${ }^{155}$ The nature of these systems is such that the anonymity of its customers is assured and the transactions are almost impossible to monitor hence performance of due diligence measures as required by law is rendered not viable. It is important to note that majority of Tanzanians are used to alternative money remittance systems, with no regulatory control, such as expedited mail services and the conveyance of money by public transport, mainly long-distance passenger buses. ${ }^{156}$

The development help to facilitate the transfer of money and transactions using tangible products that are information based on credit cards and visa cards and cell phone. There are many illegal acts conducted in obtaining bank account and payment card detail, which might easily be attempted and accessed using compromised data means that e-commerce application like banking services, are a particularly popular target for fraud and other related e-crime. ${ }^{157}$

Transferring funds by electronic messages between banks (wire transfer) can sometimes be used as a mechanism of moving the illegal profits swiftly beyond the easy reach of law enforcement agents thereby confusing the audit trail. ${ }^{158}$ Rules and regulations of the so called inter-bank financial telecommunications such as S.W.I.F.T and TISS can at times be abused by launderers to safely transfer illicit funds from one destination to another.

\footnotetext{
153 Joachimson v. Swiss Bank Corporation [1921]3 K.B 110

${ }^{154}$ Adam J .Mambi, ICT law Book: a source Book for Information and Communication Technologies and Cyber law (Dar-Es-Salaam: Mkuki na Nyota Publishers ltd 2010)179:Money Laundering which was only common under physical world, is now being committed electronically as a cyber money laundering or the use of cyber money in money laundering using mobile phones and other computer technologies which pose a great challenge to the current laws that do not address all issues related to cyber crimes. These types of crimes have resulted from misuse and exploitation of technologies and have made e-commerce in many countries unsafe.

155 Vodacom Tanzania Ltd has however, launched its Vodafone Agent Anti-money Laundering Procedures to assist in execution of Vodacom M-PESA operations

${ }^{156}$ Helen Lubengo, Combating money laundering and counter financing of terrorism: Is Tanzania up to the challenges?, Orient Journal of Law and Social Sciences Vol. III Issue 8, July 2009

157 Adam, J, Mambi, ICT Law Book a source Book For Information and Communication Technologies and cyber Law,(Dar -es-Salaam: Mkuki na Nyota Publisher, 2010),179.

${ }^{158}$ Herdman R.C., Information Technologies for the Control of Money Laundering, 1
} 


\section{International Journal of Social Sciences and Management Review}

Upon being asked on the challenges that are hampering the control of money laundering in the banking industry in Tanzania, respondents ${ }^{159}$ from the banking sector were of the view that, the period of two hours is very short so that complying with requirement of reporting STRs to the FIU within twenty four (24) hours ${ }^{160}$ becomes difficult. That, the question of ascertaining the purpose of the transaction, the origin and the ultimate destination of the funds involved, and the identity and address of the ultimate beneficiary is somehow impracticable as the bank is at the same time supposed to make sure that the beneficiary account is credited within two hours after receiving the payment instruction from the client. The control of money laundering under such circumstances is challenging as fraudsters can take advantage of such a situation to accomplish their illegal dealings.

\subsubsection{Cash-based Economy}

The cash based economy is the major reason for Tanzania being so weak in financial system. The lack of sound financial infrastructure forced people to operate outside official markets and even engage in illegal financial dealings such as money laundering. ${ }^{161}$ Most of the business activities are transacted in cash instead of paper or electronic media such as cheque or e-money. Some parts of the country do not have banking services thereby necessitating cash transactions or direct exchange of goods and services. Most of businesses do not accept personal cheque. High value assets such as real estate, motor vehicles and jewels worth millions of shillings can be bought in cash. The government is yet to put a limit on cash transaction. ${ }^{162}$

In cash- based economy usually money circulates outside the conventional financial system value transfer and remittance systems something makes the national economy prone to misuse of money laundering. ${ }^{163}$ Normally, in a predominantly cash-based economy cash transactions are not documented hence it becomes difficult to trace the true origin of the funds in such situations. The Tanzania legal framework does not have the requirement to report to the authorities all cash transactions that exceed a certain amount and subject them to the usual counter measures.

Many business transactions in Tanzania are done through cash instead of electronic or paper media. Most businesses do not accept new technologies of card based instruments such as credit cards, prepaid cards or debit cards as a medium of exchange. Consequently, purchases of high value assets such as jewels, vehicles and real assets worth millions are not regulated since they are transacted outside the purview of the banking system.

\subsubsection{Awareness and Knowledge of Money Laundering}

\footnotetext{
${ }^{159}$ Fales Kapinga, (Accountant officer, National Bank of Commerce, Songea),Telephone Interview, and Mushi (NBC bank Manager Songea Brach)Telephone Interview 3 June 2011.

${ }^{160}$ Section 17 of the Anti-Money Laundering Act, No 2 of 2006 (Cap.423)

161 Wilbert B. Kapinga,"A review of the Anti-Money Laundering System in Tanzania", The Tanzania Law Journal,(2010),36.

162 Charles Goredema, Money Laundering in East and Southern Africa: an overview of the treat, ISS Paper 2003,3.

${ }^{163}$ Mushi P.B.H., Fighting Money Laundering. The Challenges in Africa, 8
} 


\section{International Journal of Social Sciences and Management Review}

Offences of money laundering in Tanzania are unknown for the most peoples. In general there is lack of competent in terms of skills and tools to investigate prosecute and determine such offences. Many people are unaware of the evil of money laundering. This creates the challenge as to why Tanzania is worried while the people are ignorant for such offence.

\subsubsection{Weakness of the Anti-Money Laundering Laws}

Despite of having Anti money laundering Act and other legislations which provide for anti-money laundering, still there are weaknesses which are associated with combating money laundering in Tanzania. Some legislation of developed countries includes structuring ${ }^{164}$ to be the offence of money laundering. In Tanzania when looking the legislation there is no such an offence, which provides loophole to many Tanzanian to engage in money laundering without being held liable.

It is submitted that the legislation maker should amend the existing law so as to include structuring as an offence in order to facilitate the whole process of combating money laundering in Tanzania. Money laundering is still a problem all over the world specifically developing countries like Tanzania which have some impacts in the economic development; this is due to ineffectiveness of Anti money laundering laws in all aspect of controlling financial institutions as the backbone of the country economy as well as slow development of the law which end up below standard in connection to the development of technology which takes place. The researcher call upon all developing countries to accept the development which takes place in the world by amending the laws to meet the international standard especially with this critical offence of money laundering which real affect the country as well as world economy

\subsection{Money Laundering and Asset Recovery}

Asset Recovery in Tanzania is governed by the Proceeds of Crime Act. ${ }^{165}$ The PCA therefore contains the original anti money laundering provision. ${ }^{166}$ The Act focuses primarily on serious narcotic offences. The Act as amended in 2007 define proceeds of crime as any property that is derived or realized directly or indirectly, by any person out of the commission of any serious offence and includes property that was later converted, transformed or intermingled into another property; and capital, income or other economic gains derived or realized from property.

Power of search and seizure of tainted property is vested on the police. A police officer may also apply for a production order where he has reasonable grounds for suspecting that any person has possession or control of any property-tracking document in relation to an offence. ${ }^{167} \mathrm{~A}$ foreign restraining order has to be registered with the High court in terms of the Mutual Assistance Act, and property involved may be placed under a Trustee appointed by the court on application by the Attorney General. ${ }^{168}$

\footnotetext{
${ }^{164}$ It refer to a process whereby large cash deposits and other transactions are broken down into smaller amounts to avoid suspicious associated with lager amount of cash. Structuring is most commonly practiced at banks and similar financial services providers and is an integral part of surging.

165 The Proceeds of Crime Act of 1991,Cap 256 RE 2019

166 Ibid., Section 71-73

${ }^{167}$ Ibid., Section 31-37 and 58

168 Section 54-57 PCA.
} 


\section{International Journal of Social Sciences and Management Review}

The Attorney General makes application for confiscation, forfeiture and restraining orders to the High court, ${ }^{169}$ the DPP who can make an application to either High court or Magistrates court for a monitoring order for implementation by the inspector General of police, and for police officers who may make applications to magistrate court be noted that in some developed countries. For example, the United Kingdom, the General to obtain the issue of a monitoring order under the proceeds of crime Act, directing the financial institution to give information to the Inspector-General of police about transaction conducted through the account.

Normally, Tracing of asset recovery can be applied in all cases that involve predicate offences in Tanzania such as corruption, fraud and money laundering. The law to trace the proceeds of crime in Tanzania is still not adequate since no actions take place while there are a lot of cases in this aspect. ${ }^{170}$

In Tanzania there is an Act ${ }^{171}$ concerning asset recovery, but there is no any procedure of asset recovery despite of having many cases which I have discussed throughout my research that affects the country economy. This shows that enforcement mechanism is very ineffective, therefore, there is a need to improve the implementation of PCA so that to suppress the offence of money laundering.

\subsubsection{Tracing, Freezing and Confiscation of the Proceeds of Crime}

In Tanzania tracing, freezing and confiscation of the proceeds of crime is governing by The Proceeds of Crime $\mathrm{Act}^{172}$ which provides the power to police officer to search for and seize the property which was obtained in illegal activities. The confiscation of the money and property following the criminal conviction whereby an offender is ordered to pay the value of the benefit from a given crime, but it is necessary to link a particular crime to a particular benefit. ${ }^{173}$

Though in Tanzania there is a law which mandate the Director of Public Prosecutions (DPP) to freeze bank accounts and seize documents from a bank or financial institution followed suspicion of commission of serious offence of money laundering but in practice this is not the case. ${ }^{174}$ For example in the case of Amatus Joachim Liyumba ${ }^{175}$ who was the personnel of BOT, The court of law provides a penal penalty of two years imprisonment only without asset recovery, through this situations makes the continuations of the offence. Moreover, the

\footnotetext{
${ }^{169}$ Ibid., Section 9

${ }^{170}$ Charles Goredema:http://www.base/governance.org/fileadmin/docs/publications/books/asset-tracing.webversion.pdf

171 The Proceed of Crime Act of 1991 RE 2019.

172 Ibid., Section 31-37, and 58 .

173 Theodore S.Greenberg, Linda M. Samuel, Wingate Grant and Larissa Gray, Stolen Asset recovery: a good practices guide for non-conviction based asset,

174 The Proceeds of Crime Act, Section 63see also Colette Rausch,Elaine Banar,Combating Serious crime in Post conflict Societies: a handbook for-policy makers and practioners, (Washington D.C: Endowment of the United State Institute of Peace, 2006),65.

${ }^{175}$ Criminal Appeal,No.56 of 2010,The High Court of Tanzania at Dar-Es-Salaam
} 


\section{International Journal of Social Sciences and Management Review}

Act is wider in this aspect as it allows the police officer to enter into the premise to search for property, documents and seize and documents. ${ }^{176}$

Furthermore, Under the Act the Director of Public Prosecutor is empowered by the law to obtain and monitor order from the court to direct financial institution to give information to the Inspector General of the Police about transaction conducted through an account of the person who commit an offence. ${ }^{177}$

For instance, in other developed countries confiscation comes as the additional penalties whereby assets derived from crime may be confiscated. The confiscation is more advanced; if the assets subject to confiscation are no longer available compensatory assets of equal amount will be confiscated. Asset can also be confiscated from a third party unless they have been acquired bonafide by the third party and against an adequate consideration or in case the confiscation would excessively burden the bonafide third party. The legal entity as well is subject to confiscation. ${ }^{178}$ The situation is different in Tanzania that is why there are many activities of money laundering.

Despite of having the law about the tracing, freezing and confiscation of the proceeds of crime in Tanzania but the law remain only in papers or theory in practice is not the case. In Tanzania there are many money laundering acts including illegal money which is under the possession of people on various bank accounts and the people are aware of what is going on, but the government remain silent on the matter. Not only that but also there are many cases whereby people obtained property illegally but no action has been taken by the government to confiscate those properties which were obtained illegally.

\subsection{CONCLUSION AND RECOMMENDATIONS}

\subsection{Conclusion}

Tanzania is still facing an increasing number of money laundering events, not only in recent years but also immediately after independence when the government attempted to develop the economy of the country. From this paper it has been found that money laundering is a very serious crime in Tanzania since huge amounts of money end in hands of few criminals for their own personal benefits.

This crime normally has some negative impacts to the economy of the country since it involves huge amounts of money which could otherwise be spent for some other socio economic purposes. The country, however, has made some efforts to combat this crime. There are some pieces of legislations and institutions thereof, which in one way or another offer a legal basis for a war against money laundering.

Although various measures has been taken by president John Pombe Magufuli to reduce the activities of money laundering in Tanzania . Currently there are few cases of money laundering has been reported in Tanzania due to ethical personnel in financial institutions and

\footnotetext{
176 The Proceeds of Crime Act, section 65

177 The Proceeds of Crime Act ,section 68(1)

${ }^{178}$ Christian Kalin, and John G. Goldsmith, Anti money laundering: international Law Practice, (England: John Wiley\& Son Limited, 2007),325.
} 


\section{International Journal of Social Sciences and Management Review}

strictness of government in controlling the activities of money laundering. However, Other offences which amount to money laundering are not covered under the Act at the same time Bank of Tanzania and its personnel are also engaging in the commission of the offence. It is a call of this paper that the governing legislations should be reviewed so as to create a strong legal and institutional base for combating money laundering in Tanzania.

\subsection{Recommendations}

Firstly, this paper recommends amendment of the law relating to money laundering so as to include other offences which are not under the provision of the law such as structuring which are not covered under the Act, through this it gives room for many Tanzanians to engage in the offence of structuring without being detected by the authority responsible. According to the nature of the structuring offence which is associated with the division of large amount of money into different accounts in different banks needs proper provision which will guide only investigation, detection and supervision of the offence. Due to this technology there is a need for amending the law to cope with existing development.

Secondly; The Act also limits the reporting persons to be those specified under the Act. This situation creates bias since the person can discover the money laundering activities at the same time he is not required to report under the Act and therefore cannot report the offence hence lead to continuation of the offence. This paper has the view that the Act should be reviewed in this aspect so as to assure the duty of reporting an offence to everybody. Furthermore, there are many things to be reviewed in this aspect, The reporting person have the obligation of taking reasonable measures so as to report the suspects, but the Act is silent on what constitutes a reasonable measures as to the obligation of reporting person.

Thirdly, banking institutions and other financial institutions must make sure that there is a clear identification of the customer. Not only that but also there must be a clear provision under the law which deals with the actual source of the customer income. This will help the management of financial institution to ascertain and identify customers who deposit a huge amount of money without disclosing the actual source of the income. This paper suggests good system or arrangement even inclusion of the provisions under the law which will directly deal with the source of income to the customers.

\section{REFERENCES}

\section{Books}

Antoinette Verhage, The Money laundering complex and the compliance industry, New York: Routledge, 2011.

Adam, J, Mambi, ICT Law Book a source Book for Information and Communication Technologies and cyber Law. Dar-es Salaam: Mkuki na Nyota Publishers Ltd, 2010.

Bakar R Bakar, International Finance: an arena of level playing field. Dar-es-Salaam: Dar es Salaam 2007.

Brigit Helmals, Access for all: building inclusive Financial Systems. Washington: The international Bank for Reconstruction and Development/World Bank, 2006. 


\section{International Journal of Social Sciences and Management Review}

Volume: 03, Issue: 04 "July - August 2020"

ISSN 2582-0176

Christian Kalin, and John G. Goldsmith, Anti money laundering: international Law Practice. Chichester,England: John Wiley \&son limited, 2007.

Commonwealth secretariat, Combating money Laundering and Terrorist Financing: a model of best practice for the financial Sector, the professions and other Designed Businesses, Second Edition, 2006.

David B.Audretsch,Paul J.J Welfens, The new economy and economic growth in Europe and the US. Berlin: Spinger-Verlag, 2002.

Dionysios S. Demetis, Technology and Anti- money Laundering: A system Theory and Riskbased Approach. Cheltenham: Edward Edger Publishing Limited, 2010.

Donato Masciandaro, Global Financial crime: terrorism, money laundering and offshore centre. England: Ashgate Publishing Limited, 2004.

E.p.Ellinger,Eva Lomnika and Richard Hooley,Ellinger's Modern Banking Law, Oxford: Oxford University press, 2006.

Elizabeth V Mulig and L Murphy smith, Understanding and preventing money laundering, Internal Auditing and charities,2004.

Eugene Battigieg, Competition Law: Safeguarding the Customer Interest , a Comparative Analysis: Netherlands: Kluwer Law International,2009.

Frank Shanty and Patit Paban Mishra, Organized Crime: From trafficking to terrorism, Volume 1.Califonia: Library of Congress, 2008.

Guillermo Calvo,Arturo Galindo, Alejando Izuquierdo and Alejandro Microeconomic and social progress in Latin American .Washington D.C Development Bank, 2004.

Ismail A. Odeh, Anti-Money Laundering and Combating Terrorist Financing For Financing for Financial Institutions. Pennsylvania: Dorrance Publishing Co,inc, 2010.

James Brook, Payment System: Examples and Explanations. New York: Aspen Publishers, 2010.

Jeanne K.Giraldo,Harold A.Trinkunas, Terrorism Financing and State response: a comparative Perspective, Stanford: Stanford University Press, 2007.

Jorge Martinez-Vazquez, Javier Arze del Granado and Jameson Boex. Fighting Corruption in the Public Sector, Elsevier, 2007.

Jonathan Reuvid, Jim Sherlock and Devid Sherlock, International Trade: An Essential Guide to the Principles and Practices of Export. New Delhi: Replika Press Pvt Limited, 2010. 


\section{International Journal of Social Sciences and Management Review}

Kris Hinterseer, Criminal Finance: the political Economy of Money laundering in a Comparative Legal Context. Hague: Kluwer Law International, 2002.

Kjell Haunevik, Aida C Isinika, Tanzania in Transition: From Nyerere to Mkapa. Dar-esSalaam: Mkuki na Nyota Publisher Limited, 2010.

Latifah Merican Cheong,Emiko Todoroki and Sheila Jagannathan, Combating Money Laundering and Financing of Terrorism: a comprehensive Training Guide. Washington.D.C: The World Bank, 2009.

Mary Michelle Gallant, Money laundering and the proceeds of Crime: economic crime and civil remedies. Cheltenham: Edward Elgar Publishing Limited, 2005.

Mohammed El Qorchi,Samuel Munzele Maimbo and John F Wilson, Informal Funds Transfer systems: an analysis of the informal Hawala System. Washington D.C: International Monetary Funds, 2003.

Paul Allan Schott, Reference guide to anti-money Laundering and Combating the Financial of Terrorism, Washington D.C: The International Bank for Reconstruction and Development, 2006.

Peter Reuter and Edwin M.Truman, Chasing Dirty Money: the fight against money laundering, Washington D.C: Institute for International Economic, 2004.

Peter Alldrige, Money Laundering law: Forfeiture, confiscation, laundering and taxation of the Proceeds of Crime, Oxford: Hart Publishing, 2003.

Peter Gottschalk, Policing Financial crime Intelligence Strategy Implementation. Boca Raton: Brown Walker Press, 2009.

Peter J.Quik,Money Laundering:Muddying the Macroeconomy, Finance and Development,1997.

Pierre-Laurent Chatain,John Mcdowell,Cedric Mousset Paul Allan Scott and Emile Van Der does De willebois, Preventing Money Laundering and Terrorist Financing: a practical guide for Bank Supervisors. Washington D.C: The World Bank, 2009.

Prince M.Bagenda, Profiling money laundering in Eastern and Southern Africa, Chapter 3,combating Money Laundering in the SADC Sub-region: The case of Tanzania,2003.

Penn and Shea, The Law Relating to Domestic Banking, Sweet and Maxwell, London 2003.

Saresh Padmalatha, Management of banking and Financial Services. New Delhi: Dorling Kindersley Pvt limited, 2010.

Sarris,H,A and Brink,V.R, Economic policy and Welfare During Crisis and Adjustment in Tanzania .New York: Oxford University Press, 1993. 


\section{International Journal of Social Sciences and Management Review}

Volume: 03, Issue: 04 "July - August 2020"

ISSN 2582-0176

Susan Rosner, Money Laundering : Effects and Measures: Norderstedt ,Auflage,2009.

William C.Gilmore, Dirty money: the evolution of money laundering counter-measures, part 609. Belgium: Council of European publishing, 1999.

\section{Journal}

Laurent Agola, "Combating Money laundering in Tanzania: An Overview of Legal Framework", Journal of African and International Law, 3,( 2010).

Lubengo, H.," Combating money laundering and counter financing of terrorism: Is Tanzania up to the challenges?" Orient Journal of Law and Social Sciences 8, (July 2009)

Wendy Chamberlin, “The Fight Money Laundering”, Electronic Journal, 6 (2001)

Wilbert B. Kapinga, "A review of the anti-money laundering system in Tanzania", The Tanzania Law Journal (2010)

\section{Papers}

Charles Goredema, Money Laundering in Southern Africa: Incidence, Magnitude and Prospects for its Control, ISS Paper No. 92 October, 2004.

Mwema S.A., The Current situation and Counter-measures against Money Laundering: Tanzania's experience, Paper presented at the southern African Regional conference on money laundering September, $17^{\text {th }} 2002$,Johannesburg,South Africa.

Richard k. Gardon, Laundering the Proceeds of Public Sector Corruption, Research Paper Series in Legal Studies, Working Paper, March 2009

\section{Academic Report}

Brent L.Bartlett, The Negative Effect of Money Laundering on Economic Development; The Asian Development Bank, Regional Technical Assistance Project No.5967,Countering Money Laundering in The Asian and Pacific Region,(May 2002). 